\title{
PENGUKURAN PENAMPANG STRATIGRAFI DAN INTERPRETASI DATA RESISTIVITAS 1D DAN 2D UNTUK IDENTIFIKASI AKUIFER AIRTANAH DAERAH SAMBUTAN, SAMARINDA ILIR, KOTA SAMARINDA
}

\author{
Muhammad Amin Syam*, Hamzah Umar, Heryanto, Lutfi Abdul Salam, Adam Mulya \\ Giffari
}

Teknik Geologi, Fakultas Teknik, Universitas Mulawarman, Samarinda, Indonesia

*Penulis koresponden. Alamat email: muhaminsyam24@ft.unmul.ac.id

\begin{abstract}
Abstrak
Penelitian ini dimaksudkan untuk mengindentifikasi lapisan akuifer dengan menggunakan metode pengukuran penampang stratigrafi dan metode resistivitas 1D dan 2D di daerah Sambutan, Samarinda Ilir, Kota Samarinda. Dari hasil pengukuran penampang stratigrafi berdasarkan data singkapan batuan di permukaan diperoleh dua jenis lapisan yang dapat menjadi lapisan akuifer yaitu pasir dan batupasir sedang-kasar. Dari hasil pengukuran stratigrafi dan korelasi data resistivitas 1D atau VES, ditemukan 2 jenis akuifer yakni akuifer bebas berupa pasir dengan tebal $0,163 \mathrm{~m}$ pada VES 1 dan $0,13 \mathrm{~m}$ pada VES 2. Akuifer tertekan berupa batupasir sedang-kasar dengan tebal 6,71 m dan kedalaman 22,96 29,67 m pada VES 1 dan tebal 6,1 m serta kedalaman 22,79 - 28,89 m pada VES 2. Dari hasil pengukuran resistivitas 2D di dekat lokasi pengukuran VES diinterpretasi adanya lapisan akuifer pada kedalaman 19 meter dengan nilai resistivitas $40-90 \Omega \mathrm{m}$.
\end{abstract}

Kata kunci: airtanah; pengukuran penampang stratigrafi; resistivitas; Sambutan.

\begin{abstract}
This research is intended to identify the aquifer layer by using stratigraphic section measurement and 1D and 2D resistivity methods in Sambutan area, Samarinda Ilir, Samarinda City. From the results of stratigraphic measurements based on the outcrops of rock data on the surface obtained two types of layers that can become aquifer layers, namely sand and medium-coarse sandstone. From the results of stratigraphic measurements and correlation with resistivity data of 1D or VES, the aquifer layer comprised 2 types of aquifers were found, namely unconfined aquifers in the lithology of sand has thickness about $0.163 \mathrm{~m}$ at VES 1 and $0.13 \mathrm{~m}$ at VES 2. Confined aquifer in the lithology of mediumcoarse sandstone with a thickness of 6,71 m and depth 22.96-29.67 m at VES 1 and $6.1 \mathrm{~m}$ of thickness and depth of $22.79-28.89 \mathrm{~m}$ at VES 2. From the results of 2D resistivity measurements closed to VES location in Sambutan, the aquifer layer at a depth of 19 meters with a resistivity value of $40-90 \Omega \mathrm{m}$.
\end{abstract}

Keywords: groundwater; measuring section; resistivity method.

\section{Pendahuluan}

Airtanah merupakan salah satu sumberdaya yang terus menerus mengalami penurunan baik dari segi kuantitas maupun kualitas. Sedangkan, kebutuhan manusia akan sumberdaya air semakin hari semakin bertambah. Terbatasnya sumberdaya air permukaan dan belum tersedianya akses air bersih di daerah Sambutan, Samarinda Ilir, Kota 
Samarinda menjadikan airtanah menjadi sumber air utama masyarakat setempat.

Memperoleh airtanah ternyata tidaklah semudah yang dibayangkan. Airtanah tersimpan dan mengalir pada litologi bawah permukaan yang porous dan permeabel yang dinamakan akuifer. Tingkat kompleksitas dan heterogenitas geologi menjadikan sulitnya mengidentifikasi akuifer di bawah permukaan tanah.

Pengamatan lapangan sangat diperlukan untuk mengetahui sebaran litologi di permukaan hingga kemenerusannya di bawah permukaan. Pengukuran penampang stratigrafi dari singkapan batuan di permukaan dapat menjadi informasi awal ada tidaknya potensi airtanah pada daerah penelitian berdasarkan jenis litologi yang dapat menjadi lapisan pembawa airtanah atau akuifer.

Selain pengamatan lapangan, untuk menjustifikasi adanya lapisan batuan pembawa air juga dilakukan pengukuran resistivitas 1D atau Vertical Electrical Sounding dan resistivitas 2D untuk mencari adanya anomali resistivitas air di bawah permukaan yang selanjutnya hasil interpretasi data resistivitas 1D ini dikorelasikan dengan data hasil pengamatan lapangan dan juga untuk memverifikasi hasil interpretasi data resistivitas.

Daerah penelitian yang berlokasi di Sambutan, Samarinda Ilir, Kota Samarinda merupakan daerah yang sulit terhadap akses air bersih dari sumber air permukaan, sehingga penggunaan airtanah dapat menjadi solusi sulitnya akses terhadap air bersih dari sumber air permukaan. Atas alasan ini, penulis mencoba mencari sumber airtanah dengan menggabungkan metode pengukuran statigrafi dan resistivitas 1D dan 2D.

\section{Eksplorasi Airtanah}

\section{Investigasi Lapangan}

Investigasi lapangan terkait dengan potensi airtanah pada daerah penelitian dilakukan dengan measuring section atau pengukuran penampang stratigrafi. Dalam Noor (2010), pengukuran stratigrafi merupakan salah satu pekerjaan yang biasa dilakukan dalam pemetaan geologi lapangan. Ada pun pekerjaan pengukuran penampang stratigrafi dimaksudkan untuk memperoleh gambaran yang terperinci dari hubungan stratigrafi antar setiap perlapisan batuan atau satuan batuan, ketebalan setiap satuan stratigrafi, sejarah sedimentasi secara vertikal dan lingkungan pengendapan dari setiap satuan batuan.

Pengukuran stratigrafi dimaksudkan untuk memperoleh gambaran terperinci uruturutan perlapisan satuan stratigrafi, ketebalan setiap satuan stratigrafi, hubungan stratigrafi, sejarah sedimentasi dalam arah vertikal, dan lingkungan pengendapan. Pengukuran stratigrafi dari singkapan mempunyai arti penting dalam penelitian geologi. Secara umum tujuan pengukuran penampang stratigrafi adalah (Noor, 2010):

a. Mendapatkan data litologi terperinci dari urut-urutan perlapisan suatu satuan stratigrafi (formasi, kelompok, anggota dan sebagainya).

b. Mendapatkan ketebalan yang teliti dari tiap-tiap satuan stratigrafi.

c. Untuk mendapatkan dan mempelajari hubungan stratigrafi antar satuan batuan dan urut-urutan sedimentasi dalam arah vertikal secara detil dan untuk menafsirkan lingkungan pengendapan.

\section{Metode Geolistrik}

Geolistrik adalah metode geofisika yang mempelajari sifat aliran listrik dalam bumi dan bagaimana mendeteksinya di permukaan bumi. Dalam hal ini meliputi pengukuran potensial, arus, dan medan 
elektromagnetik yang terjadi, baik secara alamiah maupun akibat injeksi arus ke dalam bumi, Oleh karena itu metode geolistrik mempunyai banyak macam, termasuk di dalamnya potensial diri, polarisasi terinduksi, dan resisitivitas (Saputra, 2014).

Tiap-tiap media mempunyai sifat yang berbeda terhadap aliran listrik yang melaluinya,yang bergantung pada tahanan jenisnya. Pada metode ini, arus listrik diinjeksikan ke dalam bumi melalui dua buah elektrode arus dan beda potensial yang terjadi diukur melalui dua buah elektrode potensial. Dari hasil pengukuran arus dan beda potensial untuk setiap jarak elektrode berbeda kemudian dapat diturunkan variasi nilai tahanan jenis masing-masing lapisan bawah permukaan bumi (Suyanto, 2013).

Metode geolistrik mengasumsikan bahwa bumi mempunyai sifat homogen isotropis. Dalam kondisi yang sesungguhnya, tanah bersifat tidak homogen karena bumi terdiri atas lapisan-lapisan dengan karakteristik yang berbeda beda, sehingga nilai resistivitas yang kita peroleh merupakan nilai resistivitas yang mewakili nilai resistivitas seluruh lapisan yang terlalui oleh garis ekipotensial. Dengan mengetahui arus yang diinjeksikan dan mengukur beda potensial di sekitar tempat arus diinjeksikan, maka nilai tahanan jenis tanah dapat diperoleh. Nilai tahanan jenis yang diperoleh dari hasil pengukuran disebut sebagai resistivitas semu. (Telford et al., 1982). Untuk menghitung resistivitas semu batuan, digunakan persamaan sebagai berikut:

$$
\begin{aligned}
& \rho=K \frac{\Delta V}{I} \\
& K=\frac{2 \pi}{\left(\frac{1}{r_{1}}-\frac{1}{r_{2}}-\frac{1}{r_{3}}+\frac{1}{r_{4}}\right)}
\end{aligned}
$$

dengan

$\Delta \mathrm{V}$ : beda potensial (volt)

I : besar arus yang dialirkan (ampere)
$\mathrm{K}$ : faktor geometri konfigurasi

\section{Metodologi}

Pada penelitian ini dilakukan investigasi lapangan yakni pengukuran penampang stratigrafi sebanyak dua lintasan dan pengukuran resistivitas 1D (VES) dan 2D. Data resistivitas 1D (VES) dilakukan sebanyak dua line dan pengukuran resistivtas $2 \mathrm{D}$ sebanyak satu pengukuran dengan menggunakan konfigurasi Dipoledipole.

Data pengukuran penampang stratigrafi selanjutnya diolah dengan membuat tabel profil lintasan yang berisi tentang nama satuan, ketebalan, deskripsi dan pemerian batuan, serta lingkungan pengendapan batuan terbentuk untuk batuan sedimen.

Data resistivitas yang diperoleh baik 1D maupun 2D selanjutnya diolah untuk menghitung nilai resistivitas semu. Nilai resistivitas 1D atau VES semu dan geometri pengukuran dijadikan data masukan pada aplikasi IP2Win untuk memperoleh ke dalam dan resistivitas sebenarnya pada daerah penelitian. Dari nilai resistivitas ini kemudian diinterpretasi jenis litologi dengan bantuan data hasil pengukuran penampang stratigrafi. Tahap selanjutnya adalah membuat korelasi litologi antara data penampang stratigrafi dan VES terkait potensi airtanah daerah penelitan.

Data resistivitas 2D dan geometri pengukuran yang telah diolah selanjutnya disimpan dalam bentuk ekstensi .dat dan diimasukkan pada program pengolah data resistivitas untuk dilakukan inversi sehingga dapat dilihat variasi resistivitas batuan bawah permukaan.

\section{Hasil dan Pembahasan}

Stratigrafi Daerah Penelitian 
Pengukuran Penampang Stratigrafi dan Interpretasi Data Resistivitas 1D dan ...

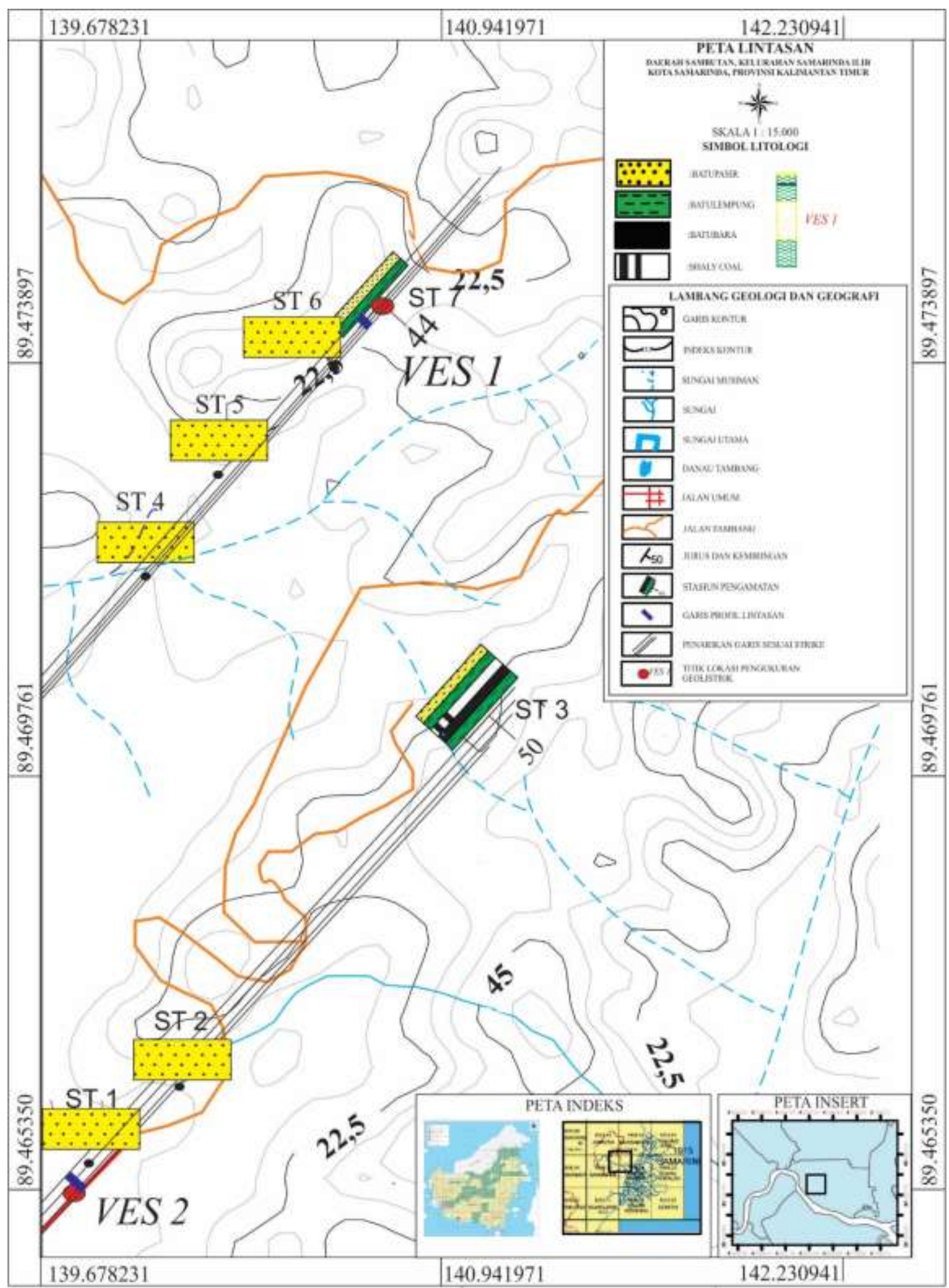

Gambar 1. Peta lokasi penelitian.

Berdasarkan litodemik resmi dan tidak resmi pada Komisi Sandi Statigrafi Indonesia Ikatan Ahli Geologi Indonesia (1996), Satuan batuan pada daerah Sambutan, Kelurahan Samarinda Ilir, Kota
Samarinda, Kalimantan Timur dibagi dan dinamakan berdasar ciri fisik dominasi litologi pada daerah penelitian yang dapat dipetakan berskala 1:25.000 serta penentuan berdasarkan pengamatan 
petrologi untuk menentukan mineral dalam satuan batuan maupun anggota satuan batuan. Adapun satuan batuan di kelompokan menjadi 3 bagian dari yang tua sampai ke yang muda (Lampiran 1), yakni:

a. Satuan Batupasir Sedang Sambutan

Satuan ini mempunyai tebal satuan batuan $\pm 2.075 \mathrm{~m}$ dan tebal singkapan $\pm 3-7 \quad m$. Satuan batupasir sedang Sambutan ini mempunyai 2 (dua) anggota satuan batuan, yaitu anggota satuan batupasir sedang dan anggota satuan batulempung laminasi.

b. Satuan Batupasir Kasar Sambutan

Berdasarkan pengukuran penampang geologi yang dibuat tegak lurus perlapisan batuan, ketebalan satuan batuan ini $\pm 2.900 \mathrm{~m}$ dan satuan batupasir kasar Sambutan memiliki 3 (tiga) anggota satuan batuan, yakni anggota satuan batulempung, anggota satuan batubara, dan anggota satuan batupasir kasar.

c. Satuan Endapan Aluvial

Satuan aluvial yang mendominasi adalah pedataran banjir. Dari aspek morfologi, satuan ini bercirikan dengan pemukiman warga, persawahan ataupun aktifitas manusia lain yang dekat dengan sungai utama. Ditemukan tanah dari batupasir kuarsa dengan tingginya oksidasi, mempunyai ketebalan sekitar 10 meter.

\section{Pengukuran Measuring Section}

Pada daerah penelitian didapatkan 7 singkapan batuan dengan kode ST 1 sampai ST 7. Singkapan yang ditemukan umumnya berupa batupasir dan perselingan batupasir, batubara, dan batulempung. Lintasan penampang stratigrafi mengikuti arah singkapan batuan ditemukan dengan mengambil 2 lintasan pengukuran penampang stratigrafi. Peta lokasi penelitian dan lokasi pengambilan data dilihat pada Gambar 1 .

Pengukuran penampang stratigrafi pada Line 1 dengan kedudukan batuan N140E/44 didapatkan empat singkapan batuan yang semuanya berupa batupasir kasar. Pada singkapan kedua ditemukan batulempung yang merupakan anggota satuan batupasir ini. Semua lapisan batupasir ini merupakan lapisan akuifer tertekan.

Pengukuran Measuring Section pada Line 2 dengan kedudukan batuan N140E/50 didapatkan tiga singkapan batuan yang semuanya juga berupa batupasir kasarsedang. Pada singkapan pertama ditemukan batulempung dan batubara yang merupakan anggota satuan batupasir ini. Semua lapisan batupasir ini merupakan lapisan akuifer tertekan dan batulempung dan batubara masing-masing merupakan akuitar dan akuiklud.

Profil penampang stratigrafi Line 1 dan Line 2 ditampilkan pada Gambar 2 dan Gambar 3. 


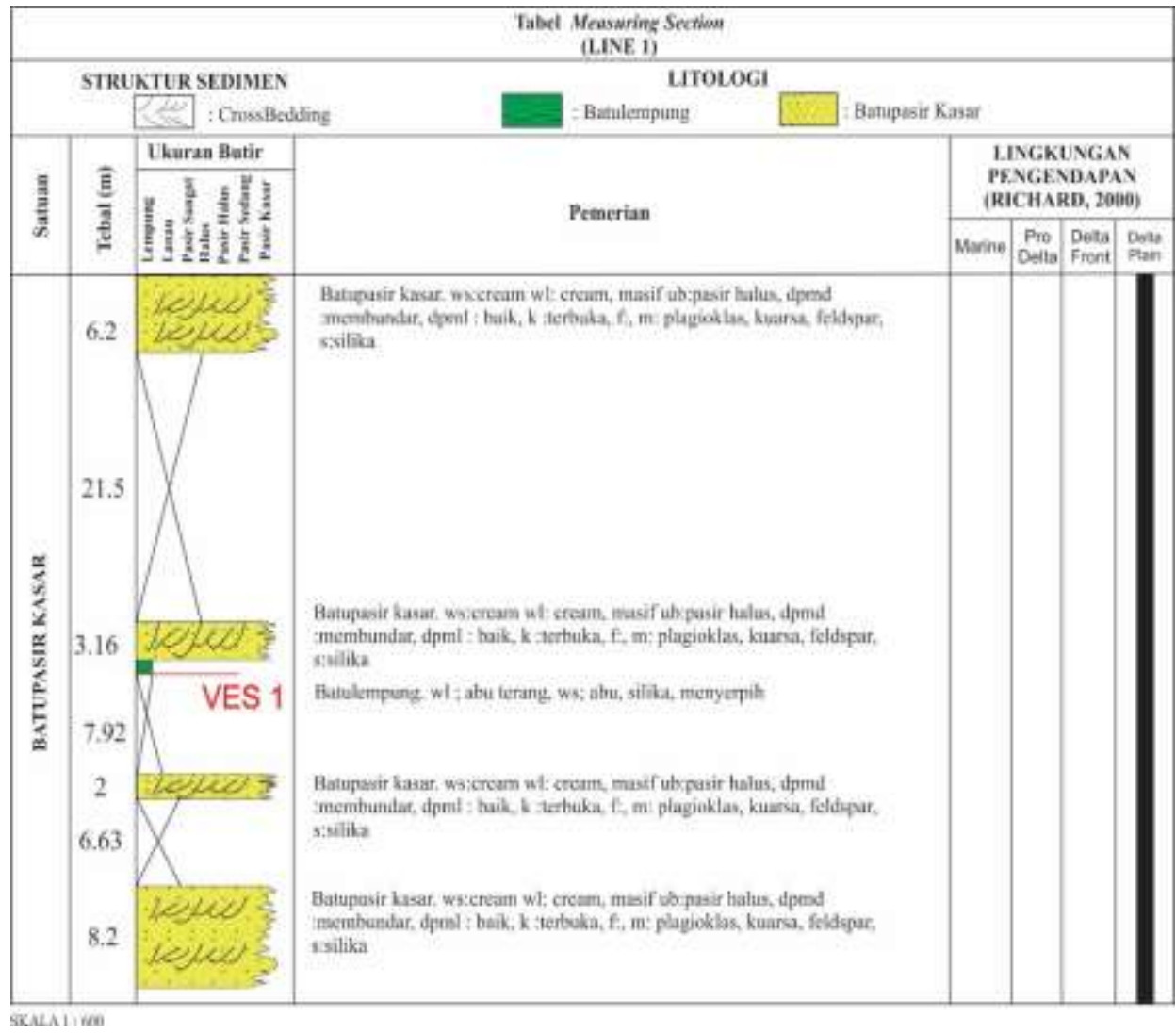

Gambar 2. Tabel pengukuran profil lintasan Line 1.

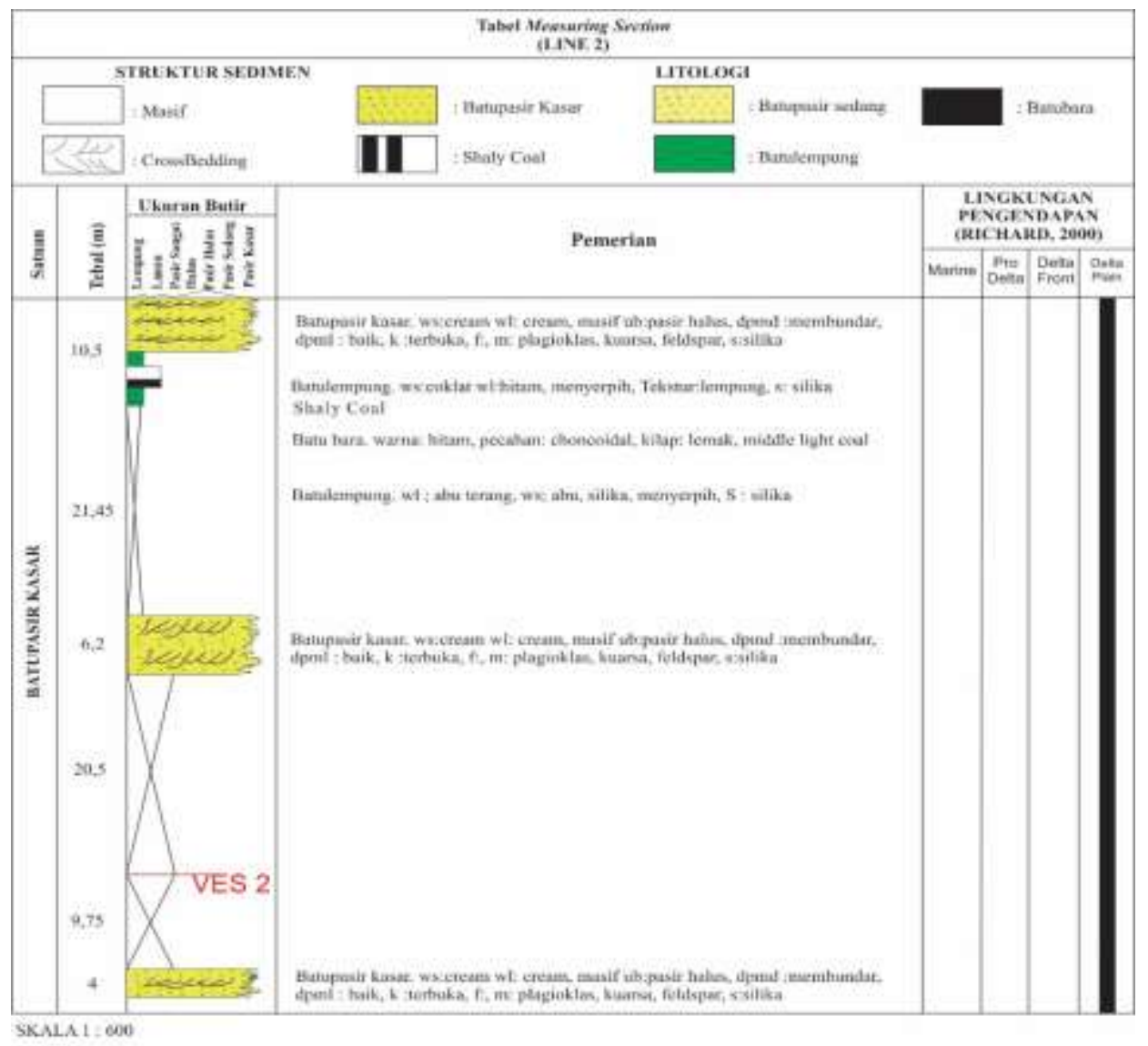

Gambar 3. Tabel pengukuran profil lintasan Line 2. 


\section{Interpretasi Data Resistivtas 1D (VES)}

Sebelum tahapan interpretasi, data VES 1 dan VES 2 terlebih dahulu diolah untuk mendapatkan nilai resistivitas semu (Lampiran 2). Selanjutnya, data nilai resistivitas semu dan geometri pengukuran dimasukkan ke aplikasi IP2Win untuk memperoleh grafik inversi, kedalaman, dan nilai resistivitas sebenarnya pada daerah penelitian (Lampiran 3). Interpretasi nilai resistivitas merujuk pada hasil penelitian Devy (2017) yang meneliti tentang kondisi hidrogeologi Kota Samarinda.

Hasil analisis data VES 1 diperoleh nilai error $1,41 \%$, dipadukan dengan data geologi permukaan maka diinterpretasi bahwa resistivitas $6,434-18,44 \Omega \mathrm{m}$ adalah batulempung, resistivitas 13,13 23,07 $\Omega \mathrm{m}$ adalah pasir (jenuh), resistivitas $33,59-94,54 \Omega \mathrm{m}$ adalah batubara, resistivitas $85,14-204,6 \Omega \mathrm{m}$ adalah batupasir kasar. Semua lapisan pasir dan batupasir merupakan lapisan akuifer dengan jenis akuifer adalah akuifer bebas dan tertekan. Secara ringkas ditampilkan pada Tabel 1.

Hasil analisis data VES 2 diperoleh nilai error $1,35 \%$ dipadukan dengan data geologi permukaan maka dapat diinterpretasi bahwa resistivitas 6,186 20,79 $\Omega \mathrm{m}$ adalah batulempung, resistivitas 11,95 - 22,99 $\Omega \mathrm{m}$ adalah pasir (jenuh), resistivitas $78,14-211 \Omega \mathrm{m}$ adalah batupasir kasar dan resistivitas 22,96 97,53 $\Omega \mathrm{m}$ adalah batubara. Dari nilai resitivitas diinterpretasi terdapat dua jenis akuifer yaitu akuifer bebas pada kedalaman 1,381 - 1,511 $\mathrm{m}$ dan akuifer tertekan pada kedalaman $22,79-28,89 \mathrm{~m}$ dari titik pengukuran. Secara ringkas ditampilkan pada Tabel 2.

Tabel 1. Nilai resistivitas hasil pengukuran VES 1

\begin{tabular}{|c|c|c|c|c|c|}
\hline NO & $\begin{array}{c}\text { Resistivitas } \\
(\Omega \mathrm{m})\end{array}$ & $\begin{array}{c}\text { Kedalaman } \\
(\mathbf{m})\end{array}$ & $\begin{array}{c}\text { Interpretasi } \\
\text { Material } \\
\end{array}$ & $\begin{array}{c}\text { Interpretasi } \\
\text { Litologi } \\
\end{array}$ & Jenis Akuifer \\
\hline 1 & $13,13-23,07$ & $1,358-1,521$ & Pasir & & Akuifer Bebas \\
\hline 2 & 7,28 & 2,675 & Batulempung & & Akuiklud \\
\hline 3 & $33,59-94,54$ & $5,078-5,808$ & Batubara & & Akuitar \\
\hline 4 & $6,399-18,44$ & $9,9985-12,84$ & Batulempung & & Akuiklud \\
\hline 5 & $85,14-204,6$ & $22,96-29,67$ & Batupasir Kasar & & Akuifer Tertekan \\
\hline 6 & 6,434 & 39,93 & Batulempung & 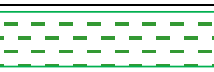 & Akuiklud \\
\hline
\end{tabular}

Tabel 2. Nilai resistivitas hasil pengukuran VES 2

\begin{tabular}{|c|c|c|c|c|c|}
\hline NO & $\begin{array}{c}\text { Resistivitas } \\
(\Omega \mathrm{m})\end{array}$ & $\begin{array}{c}\text { Kedalaman } \\
\text { (m) }\end{array}$ & $\begin{array}{c}\text { Interpretasi } \\
\text { Material }\end{array}$ & $\begin{array}{l}\text { Interpretasi } \\
\text { Litologi }\end{array}$ & Jenis Akuifer \\
\hline 1 & $11,95-22,99$ & $1,381-1,511$ & Pasir & & Akuifer Bebas \\
\hline 2 & 7,193 & 2,649 & Batulempung & & Akuiklud \\
\hline 3 & $22,96-97,53$ & $5,066-5,717$ & Batubara & & Akuitar \\
\hline 4 & $6,313-20,79$ & $9,995-12,55$ & Batulempung & & Akuiklud \\
\hline 5 & $78,14-211$ & $22,79-28,89$ & Batupasir Kasar & & Akuifer tertekan \\
\hline 6 & 6,186 & 39,9 & Batulempung & (1) & Akuiklud \\
\hline
\end{tabular}



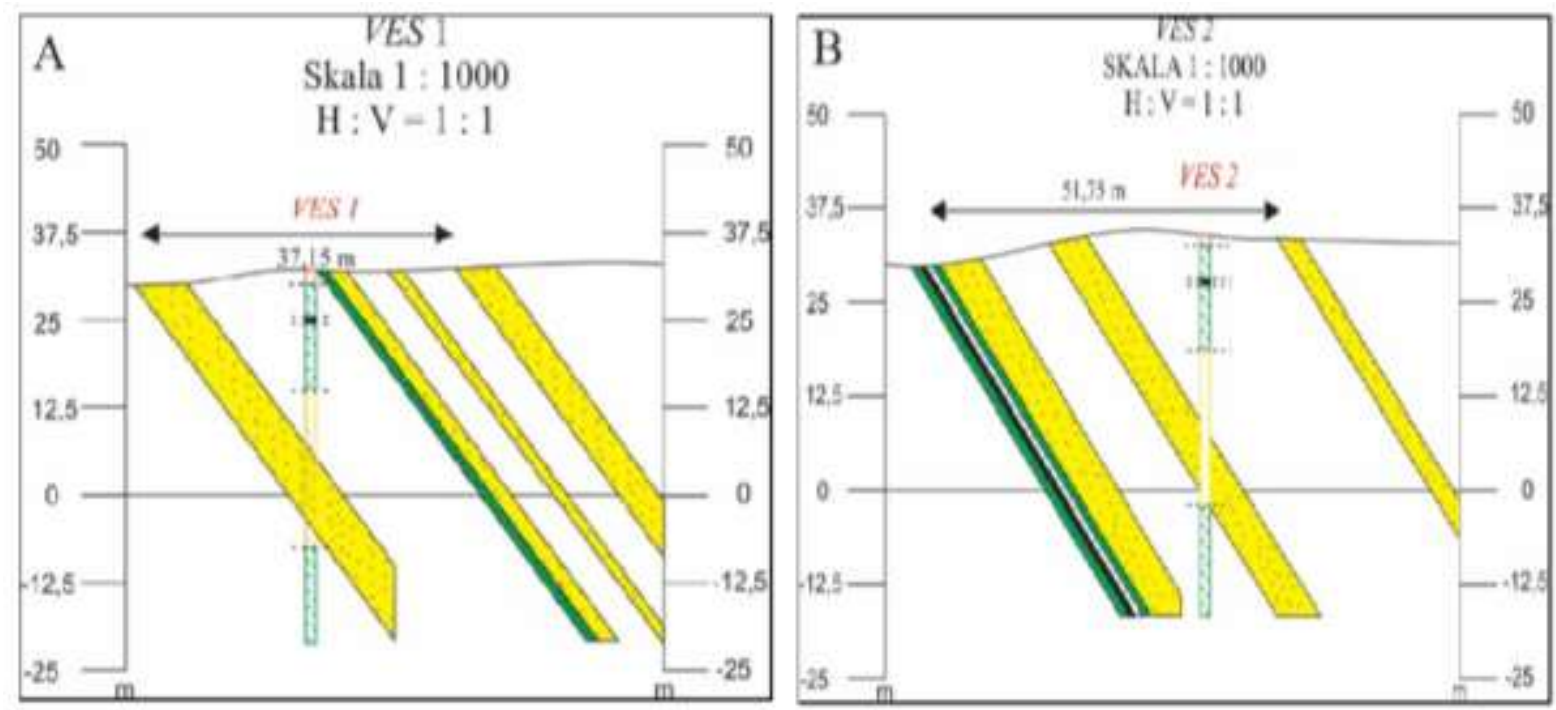

Gambar 4. Korelasi singkapan batuan (A) Line1 dan VES1, dan (B) Line 2 dan VES 2.

Setelah menginterpretasi data resistivitas 1D (VES) selanjutnya mengkorelasikannya dengan data singkapan batuan. Adanya data singkapan ini juga digunakan sebagai dasar atau acuan untuk mengintepretasi litologi bawah permukaan berdasarkan nilai resistivitasnya dengan cara menghitung kedalaman batuan yang tersingkap dari kemiringan batuan (dip) terhadap jarak antara lokasi singkapan dan titik pengukuran resistivitas 1D (VES). Korelasi tersebut dapat dilihat pada Gambar 4.

Interpretasi Data Resistivtas 2D
Selain melakukan pengukuran resistivitas 1D juga dilakukan pengukuran resistivitas 2D (Res2D) searah dip batuan menggunakan konfigurasi dipole-dipole, panjang bentangan 230 meter dan kedalaman hingga 30 meter. Jarak elektroda terkecil adalah 5 meter dengan jumlah sebanyak 6, dan total data pengukuran adalah sebanyak 609 data.

Data resistivitas 2D ini diolah terlebih dahulu untuk menghitung resistivitas semu dan selanjutnya dianalisis dengan bantuan komputeruntuk menghitung nilai resistivitas bawah permukaan secara dua dimensi.

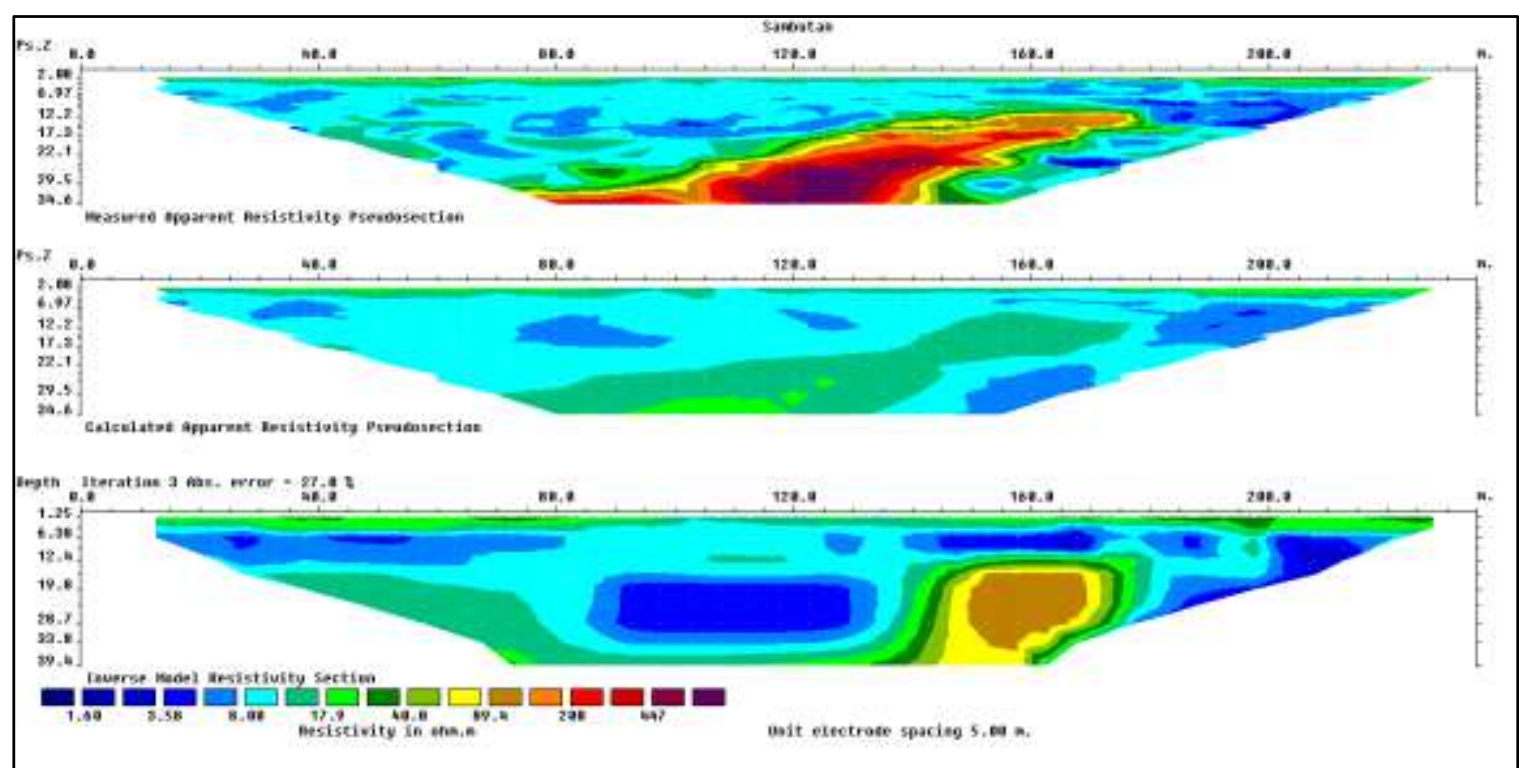

Gambar 5. Penampang resistivitas 2D. 
Dari hasil analisis data resistivitas 2D pada Gambar 5 di atas diinterpretasi bahwa adanya anomali resistivitas yang sangat rendah dengan nilai antara $1,68-40 \Omega \mathrm{m}$ merupakan lempung atau batulempung sedangkan resistivitas $40-90 \Omega \mathrm{m}$ adalah litologi yang diinterpretasi tersaturasi oleh airtanah. Model resistivitas 2D ini memiliki nilai error sebesar $27 \%$.

\section{Kesimpulan}

Berdasarkan data pengukuran stratigrafi dan survei resistivitas 1D dan 2D dapat disimpulkan bahwa:

1. Dari hasil pengukuran penampang stratigrafi (measuring section) terdapat dua litologi yang dapat menjadi lapisan akuifer yaitu batupasir kasar dan batupasir sedang.

2. Berdasarkan korelasi singkapan batuan Line 1 dan hasil VES 1 didapatkan lapisan akuifer pada kedalaman 22,96 - 29,67 m dari titik pengukuran dengan jenis akuifer adalah akuifer tertekan pada daerah penelitian.

3. Berdasarkan korelasi singkapan batuan Line 2 dan hasil VES 2 didapatkan akuifer pada kedalaman 22,79 - 28,89 $\mathrm{m}$ dari titik pengukuran dengan jenis akuifer adalah akuifer tertekan pada daerah penelitian.

4. Dari hasil pemodelan resistivitas 2D diinterpretasi terdapat adanya lapisan akuifer pada kedalaman 19 meter dengan nilai resistivitas $40-90 \Omega \mathrm{m}$.

\section{Daftar Pustaka}

Devy, D.S., Hasan, H., Nugroho, W., 2017. Hidrogeologi Kota Samarinda Provinsi Kalimantan Timur. Prosiding Seminar Nasional Teknik Sipil Universitas Mulawarman, Samarinda.

Komisi Sandi Statigrafi Indonesia Ikatan Ahli Geologi Indonesia. 1996. Sandi Stratigrafi Indonesia. IAGI.
Noor, Djauhari. 2016. Prinsip-prinsip Stratigrafi. Pakuan University Press, Bogor.

Saputra, H. 2014. Pemetaan Akuifer Air Tanah Dengan Metode Resistivitas Sounding Desa Segoroyoso, Kecamatan Pleret, Kabupaten Bantul, Provinsi Yogyakarta. Program Studi Geofisika - UGM, Yogyakarta.

Suyanto, I. 2013. Perbandingan Survei dan Analisis Data Geolistrik Sounding Daerah Pantai dan Pegunungan: Studi Kasus Penyelidikan Air Tanah di Kabupaten Kendal, Jawa Tengah, Lab. Geofisika - FMIPA UGM, Yogyakarta.

Telford, W.M., L.P. Geldart., R.E. Sheriff., D.A Keys. 1982. Applied Geophysic Second Edition. Cambridge University Press, London, Hal. 289-290, 524. 


\section{Lampiran 1. Peta Geologi Detail dan Foto Singkapan}

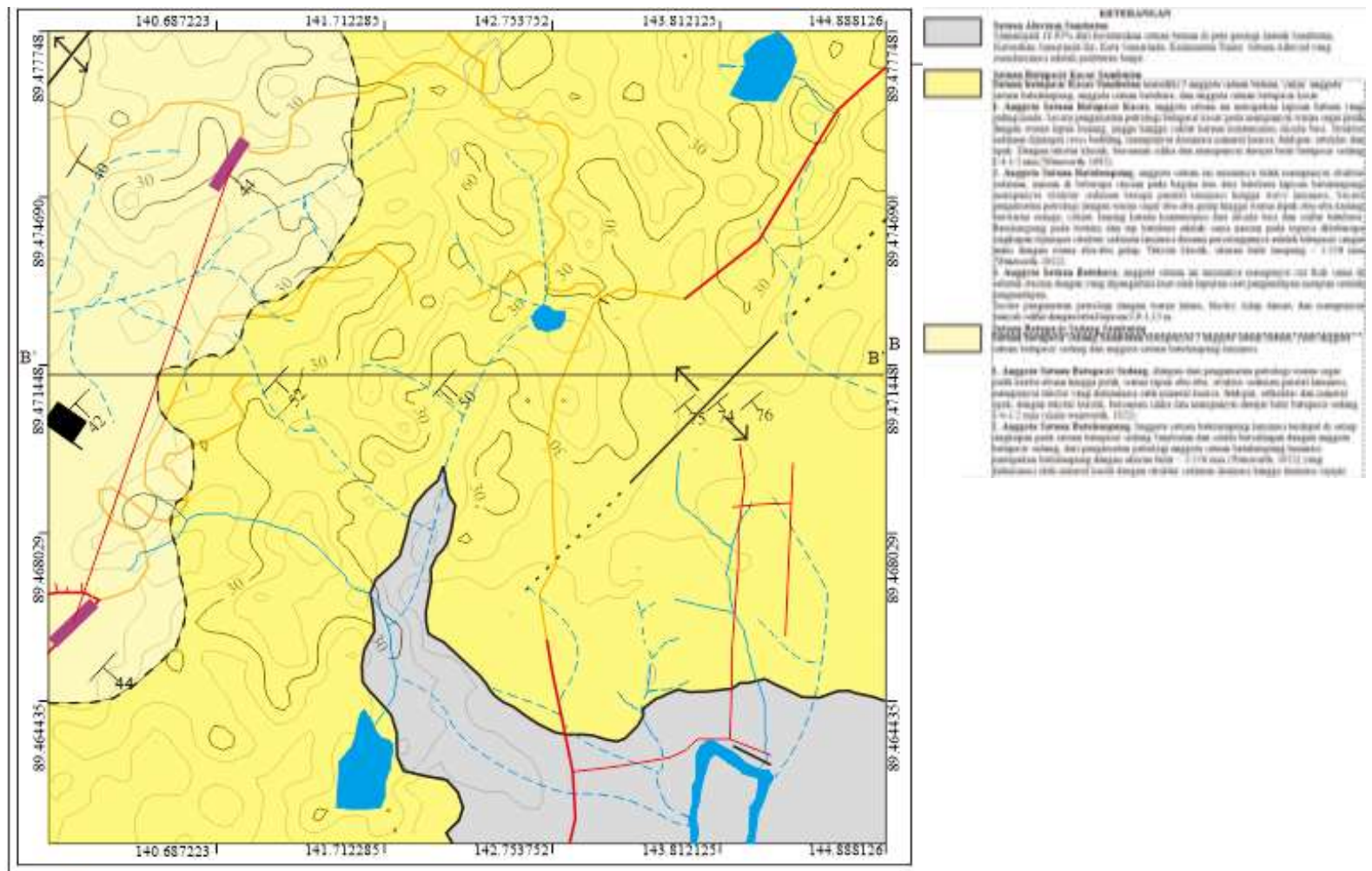

\section{Singkapan Batupasir Sedang}

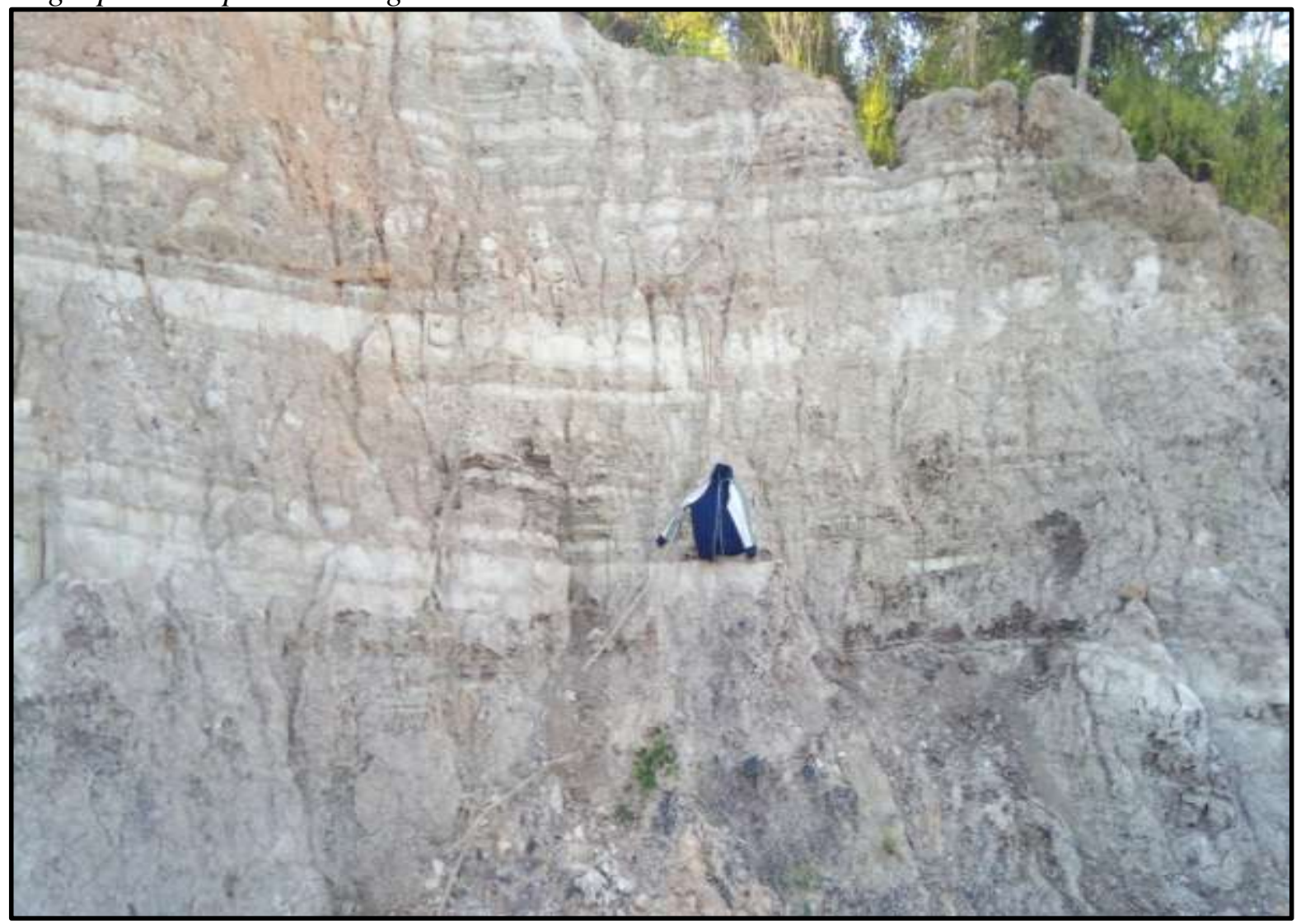




\section{Singkapan Batupasir Kasar}

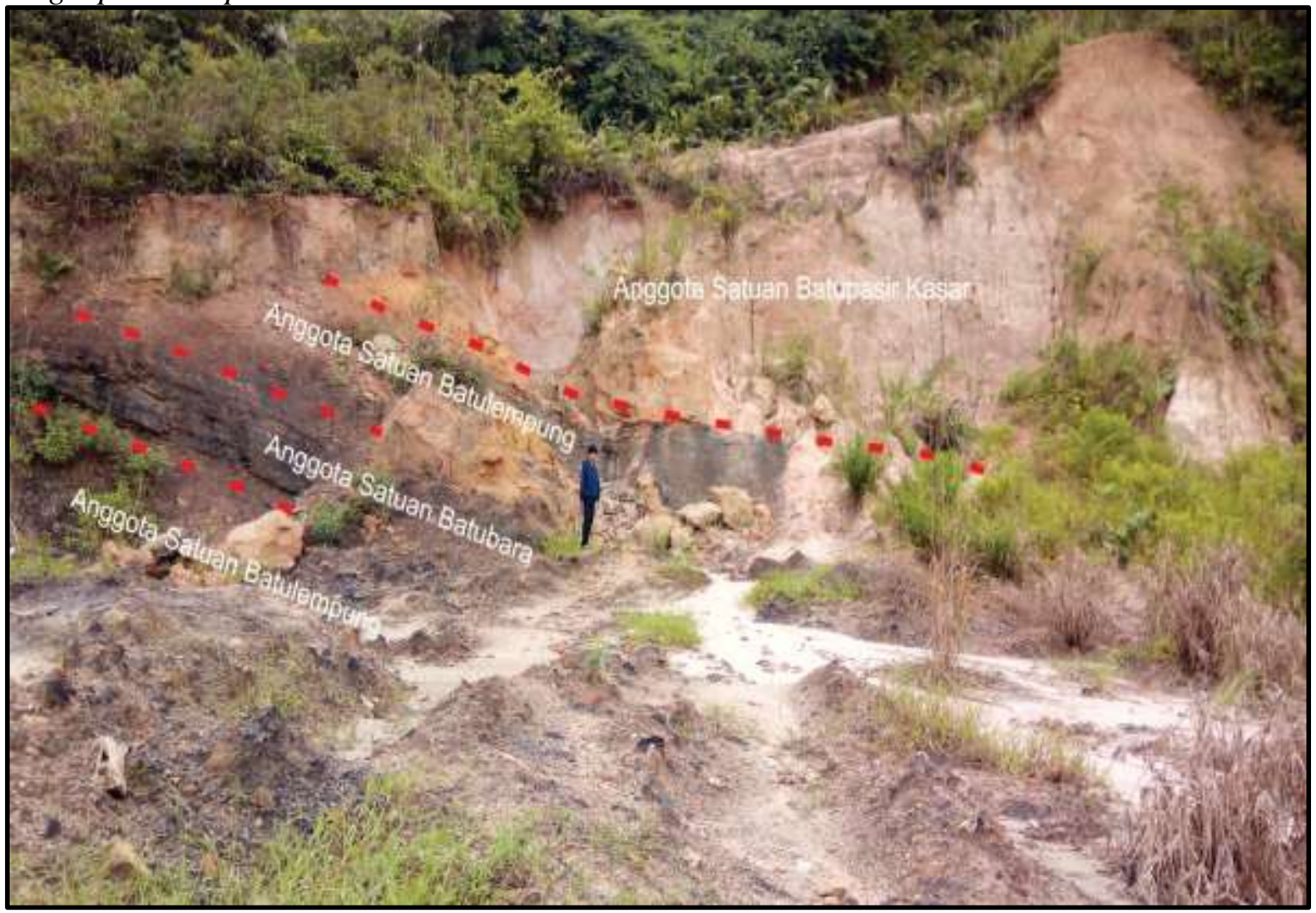

\section{Endapan Aluvium}

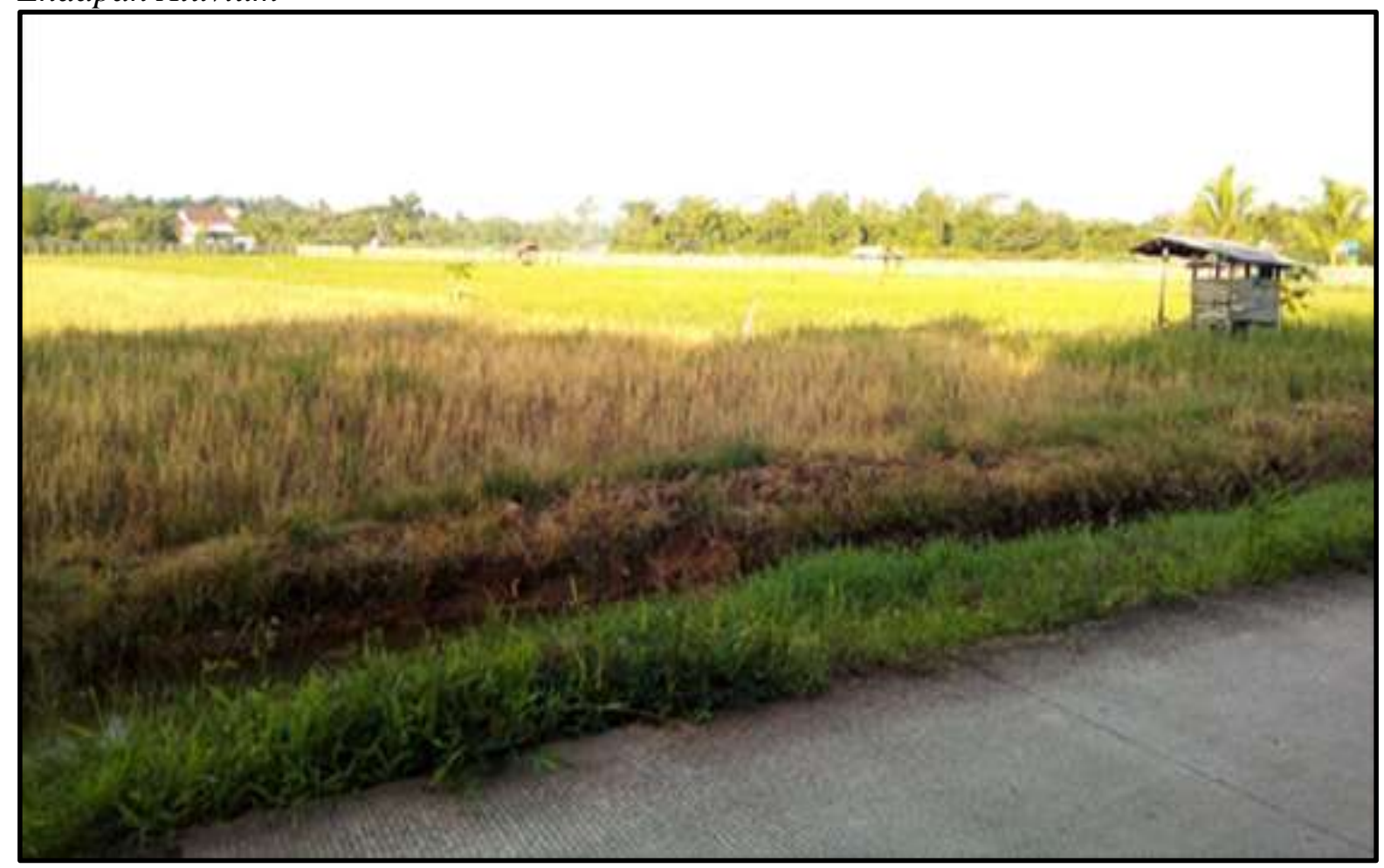




\section{Lampiran 2. Pengolahan Data VES}

Hasil data Line 1

\begin{tabular}{|c|c|c|c|c|c|c|c|c|}
\hline Lokasi: & ves 1 & & & & & & & \\
\hline Koordinat: & $\begin{array}{c}0.49103333 \mathrm{~S}, \\
117.21644500 \mathrm{E}\end{array}$ & & & & & & & \\
\hline Elevasi: & $41.3 \mathrm{~m}$ & & & & & & & \\
\hline \multicolumn{9}{|l|}{ Catatan: } \\
\hline$\underline{\mathrm{AB} / 2(\mathrm{~m})}$ & $\underline{\mathrm{MN} / 2(\mathrm{~m})}$ & $\underline{\mathbf{K}}$ & $\underline{I(m A)}$ & $\underline{\mathbf{V}(\mathbf{m V})}$ & $\underline{(\mathbf{P S})}$ & $\left(\mathbf{O}^{*} \mathbf{r}\right)$ & $\frac{\text { dev. }}{\text { st. }}$ & $\frac{\mathrm{M}}{(\mathrm{ms})}$ \\
\hline 2 & 1 & 12 & 361 & 516 & 110 & 17 & 0 & 0 \\
\hline 4 & 1 & 49 & 351 & 116 & 112 & 16 & 0 & 1 \\
\hline 6 & 1 & 112 & 323 & 52 & 114 & 18 & 0 & -2 \\
\hline 10 & 1 & 313 & 389 & 28 & 116 & 23 & 0 & 0 \\
\hline 10 & 1 & 156 & 387 & 55 & 77 & 22 & 0 & -15 \\
\hline 15 & 1 & 352 & 749 & 52 & 86 & 24 & 0 & 1 \\
\hline 25 & 1 & 980 & 851 & 21 & 96 & 24 & 0 & -32 \\
\hline 30 & 1 & 1412 & 540 & 9 & 99 & 24 & 0 & -11 \\
\hline 30 & 2 & 704 & 870 & 28 & 319 & 23 & 0 & -86 \\
\hline 35 & 2 & 959 & 328 & 8 & 301 & 25 & 0 & 3 \\
\hline 40 & 2 & 1253 & 426 & 9 & 307 & 26 & 0 & 9 \\
\hline 50 & 2 & 1960 & 456 & 7 & 317 & 28 & 0 & 11 \\
\hline 50 & 5 & 778 & 454 & 15 & 69 & 26 & 0 & -140 \\
\hline 60 & 5 & 1123 & 332 & 8 & 4 & 26 & 0 & -69 \\
\hline 70 & 5 & 1532 & 413 & 7 & -14 & 27 & 0 & -50 \\
\hline 80 & 5 & 2003 & 643 & 9 & -59 & 27 & 0 & -28 \\
\hline 100 & 5 & 3134 & 733 & 6 & -75 & 26 & 0 & -66 \\
\hline 100 & 20 & 754 & 733 & 28 & 4 & 29 & 0 & -38 \\
\hline
\end{tabular}


Hasil data Line 2

\begin{tabular}{|c|c|c|c|c|c|c|c|c|}
\hline Lokasi: & ves 2 & & & & & & & \\
\hline \multicolumn{9}{|l|}{ Koordinat: } \\
\hline \multicolumn{9}{|l|}{ Elevasi: } \\
\hline \multicolumn{9}{|l|}{ Catatan: } \\
\hline$\underline{\mathrm{AB} / 2(\mathrm{~m})}$ & $\underline{\mathrm{MN} / 2(\mathrm{~m})}$ & $\underline{\mathbf{K}}$ & $\begin{array}{c}\underline{I} \\
(\mathbf{m A}) \\
\end{array}$ & $\begin{array}{c}\underline{\mathbf{V}} \\
(\mathrm{mV})\end{array}$ & $\begin{array}{c}\underline{P S} \\
(\mathrm{mV}) \\
\end{array}$ & $\begin{array}{c}\underline{\mathbf{r}} \\
\left(\mathbf{O}^{*} \mathbf{m}\right) \\
\end{array}$ & dev. st. & $\underline{M}(\mathbf{m s})$ \\
\hline 2 & 1 & 12 & 265 & 503 & -25 & 22 & 0 & -1 \\
\hline 4 & 1 & 49 & 319 & 106 & -27 & 16 & 0 & 4 \\
\hline 6 & 1 & 112 & 324 & 44 & -28 & 15 & 0 & 5 \\
\hline 10 & 1 & 313 & 479 & 19 & -29 & 13 & 0 & 26 \\
\hline 10 & 1 & 156 & 477 & 40 & -6 & 13 & 0 & 84 \\
\hline 15 & 1 & 352 & 467 & 16 & 15 & 12 & 0 & 18 \\
\hline 25 & 1 & 980 & 303 & 4 & 14 & 11 & 0 & 18 \\
\hline 30 & 1 & 1412 & 468 & 4 & 13 & 13 & 0 & 78 \\
\hline 30 & 2 & 704 & 469 & 7 & 59 & 10 & 0 & -651 \\
\hline 35 & 2 & 959 & 260 & 4 & -4 & 16 & 0 & -25 \\
\hline 40 & 2 & 1253 & 461 & 6 & -11 & 17 & 0 & 30 \\
\hline 50 & 2 & 1960 & 268 & 2 & -13 & 13 & 0 & 126 \\
\hline 50 & 5 & 778 & 268 & 6 & 37 & 18 & 0 & 1055 \\
\hline 60 & 5 & 1123 & 285 & 5 & 41 & 19 & 0 & 452 \\
\hline 70 & 5 & 1532 & 361 & 1 & 32 & 5 & 0 & -1559 \\
\hline 80 & 5 & 2003 & 266 & 1 & 29 & 10 & 0 & -106 \\
\hline 100 & 5 & 3134 & 635 & 3 & 20 & 16 & 0 & 150 \\
\hline 100 & 20 & 754 & 634 & 10 & 170 & 12 & 0 & -606 \\
\hline
\end{tabular}




\section{Lampiran 3. Inversi Data VES}

VES 1

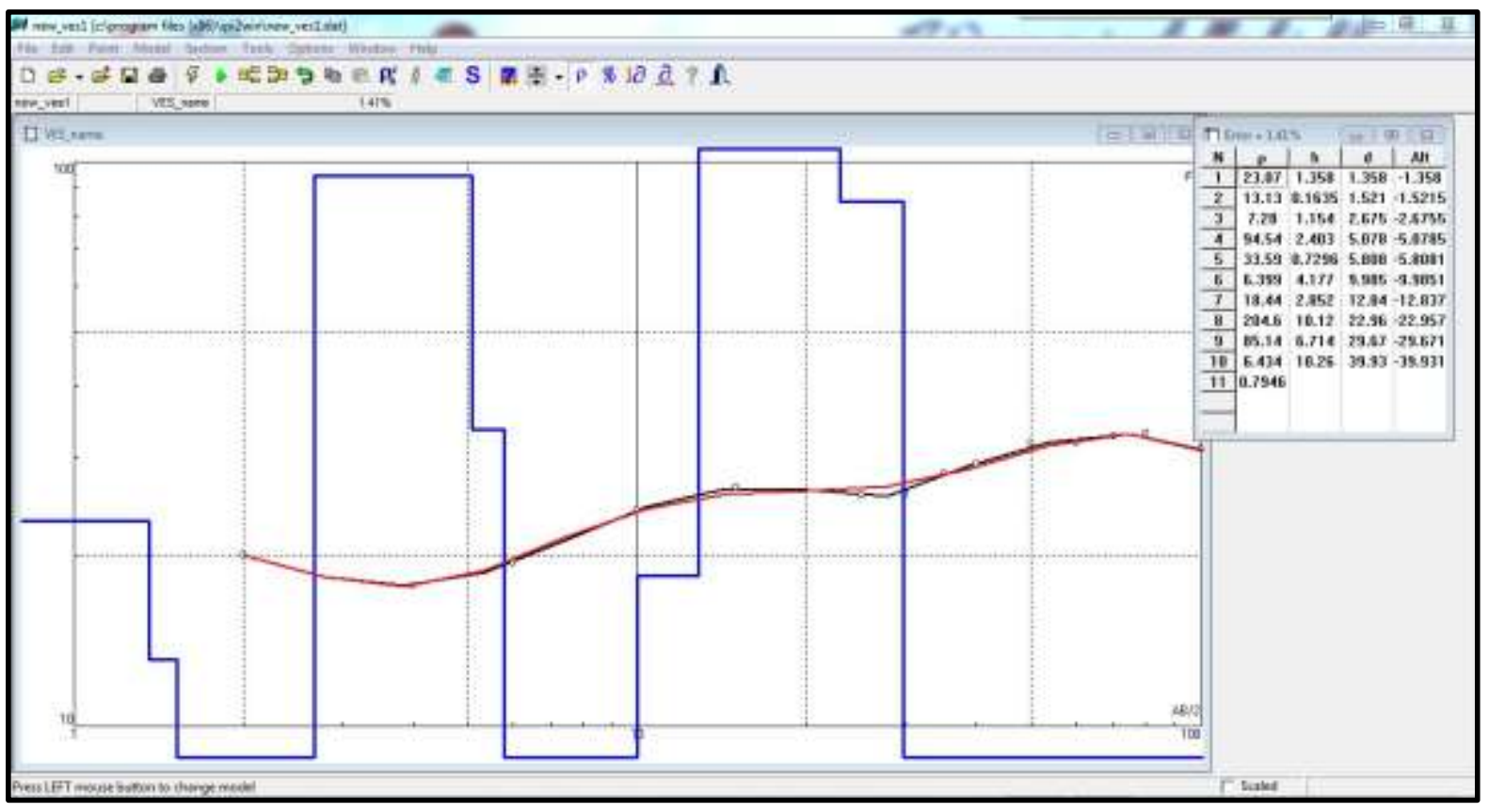

VES 2

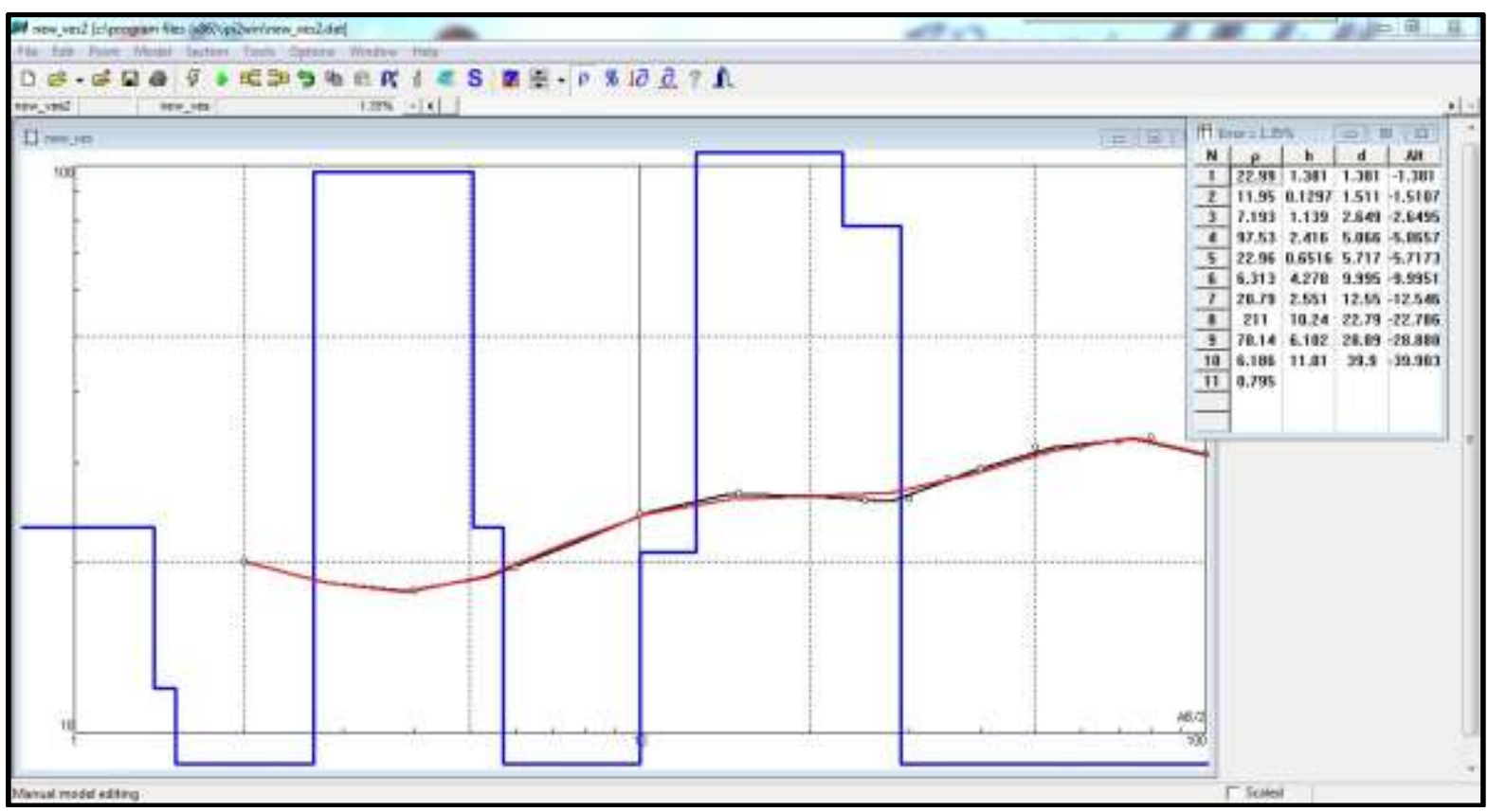

